Andrews University

Digital Commons @ Andrews University

Faculty Publications

$2-1-2005$

\title{
Ponazuril Inhibits the Development of Eimeria Vermiformis in Experimentally Infected Outbred Swiss Mice
}

\author{
S. A. Billeter \\ Auburn University \\ J. A. Spencer \\ Auburn University \\ Bill Chobotar \\ Andrews University, chob@andrews.edu \\ B. L. Blagburn \\ Auburn University
}

Follow this and additional works at: https://digitalcommons.andrews.edu/pubs

Part of the Zoology Commons

\section{Recommended Citation}

Billeter, S. A.; Spencer, J. A.; Chobotar, Bill; and Blagburn, B. L., "Ponazuril Inhibits the Development of Eimeria Vermiformis in Experimentally Infected Outbred Swiss Mice" (2005). Faculty Publications. 2173. https://digitalcommons.andrews.edu/pubs/2173

This Article is brought to you for free and open access by Digital Commons @ Andrews University. It has been accepted for inclusion in Faculty Publications by an authorized administrator of Digital Commons @ Andrews University. For more information, please contact repository@andrews.edu. 


\section{S. A. Billeter · J. A. Spencer · B. Chobotar \\ B. L. Blagburn \\ Ponazuril inhibits the development of Eimeria vermiformis in experimentally infected outbred Swiss mice}

Received: 5 August 2004/ Accepted: 23 September 2004/Published online: 23 December 2004

(C) Springer-Verlag 2004

\begin{abstract}
We evaluated a $15 \%$ paste formulation of ponazuril in outbred Swiss mice that were experimentally infected with Eimeria vermiformis. Thirty, 8-weekold female mice (approximately $20 \mathrm{~g}$ ) were placed in one group of 10 mice and one group of 20 mice. Mice in both groups were gavaged with approximately 5,000 sporulated oocysts of $E$. vermiformis on day 0 . Mice in group $2(n=10)$ were treated orally on days 3 and 4 with ponazuril (suspended in $30 \%$ propylene glycol) at the rate of $20 \mathrm{mg} / \mathrm{kg}$. Mice in group $1(n=20)$ were gavaged with a similar volume of $30 \%$ propylene glycol. Rates of oocyst passage (oocysts/g feces) were determined on day 10 (peak patency) for treated and nontreated mice using a fecal aliquot oocyst counting technique. Oocysts were not observed in the feces of treated mice using the aliquot technique. Control mice passaged oocysts at a geometric mean rate of $>104,000$ oocysts/g feces. Control mice also produced significantly less feces on day 10 . These results indicate that ponazuril is effective against $E$. vermiformis under the conditions utilized in this study, and that the E. vermiformis mouse model could be useful in predicting the efficacy of new anticoccidial drugs.
\end{abstract}

\section{Introduction}

Coccidiosis is a cosmopolitan disease in both food and companion animals. Although the term coccidia generally refers to numerous related genera of apicomplexan protozoan parasites, traditional reference to coccidiosis

\footnotetext{
S. A. Billeter · J. A. Spencer $\cdot$ B. L. Blagburn $(\square)$

College of Veterinary Medicine,

Auburn University, Auburn, AL 36849, USA

E-mail: blagbbl@vetmed.auburn.edu

Fax: + 1-334-8442652

B. Chobotar

Department of Biology, Andrews University,

Berrien Springs, MI 49104, USA
}

implied that the causative agents were apicomplexan protozoan parasites of the genera Eimeria or Isospora. Numerous anticoccidial agents are available for the treatment of livestock and poultry coccidiosis (Long 1990). However, there are few approved anticoccidial medications for other species such as dogs and cats (Lindsay and Blagburn 1991). Convenient and representative animal models for the study of the biological and chemotherapeutic aspects of coccidiosis would be helpful in identifying effective candidate anticoccidial medications in these and other host species.

Eimeria vermiformis is a pathogenic coccidium known to infect several laboratory strains of Mus musculus (Rose et al. 1997a). Numerous previous studies have demonstrated that E. vermiformis can be an effective model species for the study of the developmental, pathogenetic, immunological, ultrastructural, and genetic aspects of coccidiosis (Blagburn et al. 1982; Blagburn and Todd 1984, 1986; Rose et al. 1997b; Smith and Hayday 2000).

Ponazuril is the sulfone derivative of toltrazuril, a triazinetrione anticoccidial medication that is effective in the treatment of coccidiosis caused by both Eimeria and Isospora spp. in a variety of host species (Lech 2002). Ponazuril also is the active ingredient in a paste formulation approved for the treatment of equine protozoal myeloencephalitis in horses (Furr et al. 2001). In the present communication, we investigated the capability of ponazuril to inhibit the development of E. vermiformis in experimentally infected outbred Swiss mice. The successful development of this model could result in its use in the evaluation of other potentially effective anticoccidial agents.

\section{Materials and methods}

Source and propagation of E. vermiformis

Oocysts of E. vermiformis were maintained and propagated periodically in outbred Swiss mice in the labora- 
tory of one of the authors (B.C.). Sporulated oocysts were shipped to Auburn University in $2.5 \%$ potassium dichromate $\left(\mathrm{K}_{2} \mathrm{Cr}_{2} \mathrm{O}_{7}\right)$ solution. The $\mathrm{K}_{2} \mathrm{Cr}_{2} \mathrm{O}_{7}$ was removed by repeated centrifugation and washing in Hanks' balanced salt solution. To acquire sufficient numbers of oocysts for conducting the experiments reported here, four female, 8-week-old Swiss mice (Harlan Sprague Dawley, Indianapolis, Ind., USA) were each gavaged with 2,000 sporulated oocysts. This inoculum level was selected to obtain a maximum yield of oocysts without the induction of clinical disease, and was based on our previous experience with this parasite (Blagburn and Todd 1984). For collection of $F_{1}$ oocysts, mice were placed in wire-bottomed cages on postinfection days 8-12. Feces were collected in pans beneath the cages to which $2.5 \% \mathrm{~K}_{2} \mathrm{Cr}_{2} \mathrm{O}_{7}$ was added. During patency, sample days were collected separately to determine on which collection day peak patency occurred. The feces $/ \mathrm{K}_{2} \mathrm{Cr}_{2} \mathrm{O}_{7}$ mixture for each day's collection was placed in $500 \mathrm{ml}$ bottles and maintained for 7 days under forced aeration to allow the oocysts to sporulate. Oocysts were purified using a Sheather's sucrose flotation procedure (Hammond et al. 1968) and stored in $2.5 \% \quad \mathrm{~K}_{2} \mathrm{Cr}_{2} \mathrm{O}_{7}$ solution at $4^{\circ} \mathrm{C}$ for approximately 2 weeks before they were used. Prior to inoculation into mice, the $\mathrm{K}_{2} \mathrm{Cr}_{2} \mathrm{O}_{7}$ was removed as previously described. Oocysts were enumerated with the aid of a hemacytometer.

\section{Mice}

Thirty female, 8-week-old mice were obtained from a commercial supplier (Harlan/Sprague Dawley). Mice were housed as groups of five in box cages containing ground corn cobs as bedding (Harlan Teklad, Madison, Wis., USA). Water and a standard laboratory ration (Harlan Teklad) were provided ad libitum. Mice were separated into two groups of 20 mice and 10 mice, respectively. The mice weighed approximately $20 \mathrm{~g}$ at the initiation of the experiment.

Infection with E. vermiformis and treatment with ponazuril

On study day 0 , mice in both groups were inoculated by oral gavage with 5,000 sporulated E. vermiformis oocysts in approximately $0.25 \mathrm{ml}$ of HBSS. This challenge infection rate was selected to provide a moderate pathogen challenge without inducing high mortality (Blagburn and Todd 1984). A $15 \%$ paste formulation of ponazuril (Marquis) was obtained from Bayer HealthCare, Shawnee Mission, Kan. (Lech 2002). For treatment of mice, a suspension of ponazuril in a $30 \%$ solution of propylene glycol was created by adding $80 \mathrm{mg}$ of formulated paste to $3 \mathrm{ml}$ of $30 \%$ propylene glycol. On each of days 3 and 4 after infection, group 2 mice $(n=10)$ were each treated orally with ponazuril in propylene glycol at a dosage of $20 \mathrm{mg} / \mathrm{kg}$ (volume $=0.1 \mathrm{ml}$ ). Group 1 mice were each treated orally with an equal volume (approximately $0.1 \mathrm{ml}$ ) of $30 \%$ propylene glycol without ponazuril. Dosing was achieved by adding the ponazuril suspension and propylene glycol diluent to a $1 \mathrm{cc}$ tuberculin syringe to which a 22 gauge gavage needle was attached. During the propagation procedure, we observed that day 10 was the day on which the greatest number of E. vermiformis oocysts were passaged by infected mice. This is also consistent with our previous research (Blagburn and Todd 1984). Consequently, we elected to collect feces from all group 1 and group 2 mice on day 10 after infection (6 days after the last treatment). For fecal collection, mice were placed individually in plastic containers for 20 min. Fecal specimens were weighed and then transferred to plastic vials (Fisher Scientific, Suwanee, Ga., USA) containing $1 \mathrm{ml}$ of $2.5 \% \quad \mathrm{~K}_{2} \mathrm{Cr}_{2} \mathrm{O}_{7}$ and stored at room temperature $\left(22^{\circ} \mathrm{C}\right)$ until oocysts were enumerated.

\section{Oocyst enumeration/ponazuril efficacy determination}

Fecal specimens collected on day 10 were examined for E. vermiformis oocysts using a Sheather's sucrose flotation procedure. Briefly, the mixture of $\mathrm{K}_{2} \mathrm{Cr}_{2} \mathrm{O}_{7}$ and feces were mixed thoroughly in a paraffinized cup. The liquid was then poured through a tea strainer into a second cup. The filtrate was added to a $16 \times 100 \mathrm{~mm}$ glass tube and centrifuged at $250 \mathrm{~g}$ for $5 \mathrm{~min}$. A pipette attached to a vacuum system was used to remove the supernatant above the pelleted particulate debris. Sheather's sucrose (SG 1.20) was added to the tube and mixed thoroughly with the debris. The tube was returned to the centrifuge and filled with Sheather's sucrose to form a meniscus. A 23-mm square cover slip was placed on the glass tube and the preparation was again centrifuged for $10 \mathrm{~min}$ at approximately $60 \mathrm{~g}$. The cover slip was removed and placed on a $1 \times 3$ " glass slide.

Because of the high numbers of oocysts present in the fecal specimens from control mice, an aliquot technique was employed for the enumeration of $E$. vermiformis oocysts. Six high-power $(400 \times)$ fields were visualized in the center of the cover slip and all oocysts present in the six fields were counted. The fields that were counted were located in the same positions on all of the slides.

The efficacy of ponazuril was determined by comparing the number of oocysts recovered from treated versus control mice on day 10 using the following formula: geometric mean number of oocysts recovered from control mice minus geometric mean number of oocysts from treated mice divided by the geometric mean number of oocysts recovered from control mice $\times 100$. Fecal and oocyst outputs were compared on day 10 using Student's $t$-test (SAS, Cary, N.C., USA). All data were converted to $\log _{10}$ prior to statistical 
analysis. Determination of statistical significance was based on a significance level of $P<0.05$.

\section{Results and discussion}

Treatment with ponazuril or propylene glycol appeared safe since no adverse clinical sign that could be associated with the administration of either of these agents was observed. One moribund mouse in the ponazuriltreated group (group 2) was killed on study day 4 . We attributed the moribund state of this animal to esophageal trauma induced by the gavage needle. A nontreated mouse (group 1) was killed on study day 9 because of ataxia which we attributed to signs of $E$. vermiformisinduced coccidiosis. Day 9 is the time at which mice in previous studies were observed to succumb to coccidiosis (Blagburn and Todd 1984). The remaining nontreated mice appeared unkempt with poor quality hair coats. They tended to huddle in groups in their respective cages. Mice treated with ponazuril appeared clinically normal. All were active and had normal healthy hair coats.

The results of E. vermiformis fecal oocyst counts on study day 10 are presented in Table 1 . Fecal samples were successfully obtained from 18 nontreated (group 1) mice and 9 treated (group 2) mice on day 10. One nontreated mouse did not defecate during the allotted time. The geometric mean number of $E$. vermiformis oocysts per gram of feces recovered from nontreated mice exceeded 104,000 (range $=10,773-549,990$, Table 1). Oocysts were not observed in the six-field aliquots examined in any of the ponazuril-treated mice, indicating that ponazuril was effective in inhibiting development of $E$. vermiformis $(P=0.0013)$. However, because we did not examine each slide entirely, we cannot state with certainty that oocysts were not present in the feces of treated mice. The amount of feces obtained from treated mice on study day 10 was significantly greater than the amount of feces obtained from nontreated mice $(P=0.0041)$. This was probably due to reduced appetite in nontreated mice and their reduced food consumption. However, since we did not measure food consumption for individual animals, we cannot rule out other possible causes for the differences in fecal output on day 10. Reduced food consumption is a common clinical sign of coccidiosis in clinically ill animals (Long 1990).

The results of the present study indicate that ponazuril is effective in the treatment of coccidiosis caused
Table 1 Day 10 fecal outputs and oocyst counts from Eimeria vermiformis infected mice treated orally on days 3 and 4 after infection with either $30 \%$ propylene glycol (group 1) or ponazuril (20 mg/kg, group 2). Feces were obtained from 18 control mice and nine treated mice on day 10 a,b Means with different superscripts are significantly different $(\mathrm{P}<0.05)$

*Geometric mean no. of oocysts from control mice-Geometric mean no. of oocysts from treated mice $\times$ Geometric mean no. of oocysts from control mice

\begin{tabular}{|c|c|c|c|}
\hline $\begin{array}{l}\text { (TX group-sample } \\
\text { number) }\end{array}$ & $\begin{array}{l}\text { Total number } \\
\text { of oocysts in an aliquot } \\
\text { count of six } \\
\text { microscope fields }\end{array}$ & $\begin{array}{l}\text { Amount of feces } \\
\text { in sample }(\mathrm{g})\end{array}$ & $\begin{array}{l}\text { Oocysts per gram of feces } \\
\text { based on aliquot count }\end{array}$ \\
\hline \multicolumn{4}{|c|}{ Group 1 (nontreated) } \\
\hline $1-1$ & 776.0 & 0.08 & 549,990 \\
\hline $1-2$ & 35.0 & 0.11 & 18,039 \\
\hline $1-3$ & 19.0 & 0.10 & 10,773 \\
\hline $1-4$ & 415.0 & 0.37 & 63,532 \\
\hline $1-5$ & 124.0 & 0.14 & 50,200 \\
\hline $1-6$ & 183.0 & 0,08 & 129,701 \\
\hline $1-7$ & 242.0 & 0.07 & 196,079 \\
\hline $1-8$ & 97.0 & 0.02 & 274,995 \\
\hline $1-9$ & 176.0 & 0.06 & 165,655 \\
\hline $1-10$ & 93.0 & 0.20 & 26,366 \\
\hline $1-11$ & 230.0 & 0.06 & 216,481 \\
\hline $1-12$ & 324.0 & 0.12 & 153,029 \\
\hline $1-13$ & 655.0 & 0.12 & 309,364 \\
\hline $1-14$ & 197.0 & 0.06 & 185,420 \\
\hline $1-15$ & 102.0 & 0.19 & 30,421 \\
\hline $1-16$ & 358.0 & 0.10 & 202,986 \\
\hline $1-17$ & 139.0 & 0.09 & 87,561 \\
\hline $1-18$ & 557.0 & 0.16 & 197,387 \\
\hline Geometric mean & 182.6 & $0.10^{\mathrm{a}}$ & $104,240^{\mathrm{a}}$ \\
\hline \multicolumn{4}{|l|}{ Group 2 (ponazuril) } \\
\hline $2-1$ & 0 & 0.31 & 0 \\
\hline $2-2$ & 0 & 0.23 & 0 \\
\hline $2-3$ & 0 & 0.18 & 0 \\
\hline $2-4$ & 0 & 0.17 & 0 \\
\hline $2-5$ & 0 & 0.07 & 0 \\
\hline $2-6$ & 0 & 0.14 & 0 \\
\hline $2-7$ & 0 & 0.23 & 0 \\
\hline $2-8$ & 0 & 0.42 & 0 \\
\hline $2-9$ & 0 & 0.36 & 0 \\
\hline \multirow[t]{2}{*}{ Geometric mean } & 0 & $0.21^{\mathrm{b}}$ & $0^{\mathrm{b}}$ \\
\hline & Efficacy* & & $100 \%$ \\
\hline
\end{tabular}


by $E$. vermiformis. Because ponazuril was administered after inoculation with $E$. vermiformis oocysts and during active replication in the host, the observed results are due to the therapeutic effects of this drug.

Ponazuril is the sulfone metabolite of toltrazuril and is formed when the parent molecule is metabolized within the host (Lech 2002). As mentioned previously, either the parent molecule, toltrazuril, or ponazuril was demonstrated previously to be effective against the intracellular stages of numerous coccidia or coccidia-like organisms (Haberkorn 1996; Daugschies 2000; Lindsay et al. 2000; Lloyd and Smith 2001; Mundt et al. 2003); therefore one could expect that ponazuril would also possess a similar broad spectrum of activity. In fact, specific studies indicate that ponazuril is effective against Neospora caninum (also referred to as Hammondia heydorni) and Isospora suis (Gottstein et al. 2001; Kalthoff 2001; Mundt et al. 2003). Ponazuril was completely effective when administered at $20 \mathrm{mg} / \mathrm{kg} 2$ days after the experimental inoculation of pigs with I. suis. Treatment after 2 days inhibited further development of the parasite, but did not prevent the development of lesions in the gut (Kalthoff 2001). Results of the present study appear to show complete efficacy, even though the drug was initially administered 3 days after infection. Differences in this and the previous study were probably due to differences in the length of the life cycle of $I$. suis and E. vermiformis. Ponazuril or toltrazuril was also effective against Toxoplasma gondii in experimentally infected cats (Rommel et al. 1987) or $N$. caninum in mice (Gottstein et al. 2001).

The results obtained using ponazuril and experimental E. vermiformis infections in Swiss mice as described here are similar to the observed efficacies of ponazuril or the parent molecule toltrazuril against coccidia in numerous hosts. The methodologies that we employed were convenient and straightforward and could be reproduced easily in most research facilities. The Swiss mouse $/ E$. vermiformis model used in the present study could be validly and conveniently employed to identify future effective anticoccidial agents. This is especially important for other coccidial species and in hosts for which few approved anticoccidial agents exist.

Acknowledgments This research was reviewed and subsequently approved by the Auburn University Institutional Animal Care and Use Committee.

\section{References}

Blagburn BL, Todd KSJr (1984) Pathological changes and immunity associated with experimental Eimeria vermiformis infections in Mus musculus. J Protozool 31:556-561
Blagburn BL, Todd KSJr (1986) Scanning electron microscopy of the ileum of mice (Mus musculus) infected with Eimeria vermiformis. Trans Am Microsc Soc 105:274-281

Blagburn BL, Adams JH, Todd KS Jr (1982) First asexual generation of Eimeria vermiformis Ernst, Chobotar, and Hammond, 1971 in Mus musculus. J Parasitol 68:1178-1180

Daugschies A, Mundt H, Letkova (2000) Toltrazuril treatment of cystoisosporosis in dogs under experimental and field conditions. Parasitol Res 86:797-799

Furr M, Kennedy T, Mackay T, Reed S, Andrews F, Bernard B, Bain F, Byars D (2001) Efficacy of ponazuril $15 \%$ oral paste as a treatment for equine protozoal myeloencephalitis. Vet Ther 2:215-222

Gottstein B, Eperon S, Dai WJ, Cannas A, Hemphill A, Greif G (2001) Efficacy of toltrazuril and ponazuril against experimental Neospora caninum infection in mice. Parasitol Res 87:43-48

Haberkorn A (1996) Chemotherapy of human and animal coccidiosis: state and perspectives. Parasitol Res 82:193-199

Hammond DM, Chobotar B, Ernst JV (1968) Cytological observations on sporozoites of Eimeria bovis and E. auburnensis and eimerian species from the ord kangaroo rat. J Parasitol 54:550558

Kalthoff V (2001) Investigations on the efficacy and mode of action of ponazuril (Bay Vi 9143) against Isospora suis in suckling pigs. Thesis, Freie Universität Berlin, Berlin

Lech PJ (2002) Ponazuril. Compend Cont Ed Pract Vet 24:484-485

Lindsay DS, Blagburn BL (1991) Coccidial parasites of cats and dogs. Compend Cont Ed Pract Vet 13:759-765

Lindsay DS, Dubey JP, Kennedy TJ (2000) Determination of the activity of ponazuril against Sarcocystis neurona in cell cultures. Vet Parasitol 92:165-167

Lloyd S, Smith J (2001) Activity of toltrazuril and diclazuril against Isospora species in kittens and puppies. Vet Rec 148:509-511

Long PL (ed) (1990) Coccidiosis of man and domestic animals. CRC, Boca Raton

Mundt HC, Daugschies A, Wustenberg S, Zimmerman M (2003) Studies on the efficacy of toltrazuril, diclazuril and sulphadimidine against artificial infection with Isospora suis in piglets. Parasitol Res 90: S160-S162

Rommel M, Schneider T, Krause HD, Westerhoff J (1987) Trials to suppress the formation of oocysts and cysts of Toxoplasma gondii in cats by medication of the feed with toltrazuril. Vet Med Rev 2:141-153

Rose ME, Hesketh P, Wakelin D (1997a) Oral vaccination against coccidiosis: responses in strains of mice that differ in susceptibility to infection to infection with Eimeria vermiformis. Infect Immun 65:1808-1813

Rose ME, Hesketh P, Wakelin D (1997b) Oral vaccination against coccidiosis: responses in strains of mice that differ in susceptibility to Eimeria vermiformis. Infect Immun 65:1808-1813

Smith AL, Hayday AC (2000) Genetic dissection of primary and secondary responses to a widespread natural pathogen of the gut, Eimeria vermiformis. Infect Immun 68:6273-6280 